\title{
Two Dimensional Modeling of Au/n-GaN Schottky Device
}

\author{
Bengül METIN ${ }^{1 *}$, Neşe KAVASOĞLU², Abdulkadir Sertap KAVASOĞLU²
}

\begin{abstract}
The current-voltage characteristics are powerfully affected by the lateral inhomogeneity. We developed two dimensional (2D) simulation model for Au/n-GaN Schottky device. In previous studies, it is assumed that zero barrier height inhomogeneity of the device generally good agreement with the Gaussian distribution. In this study, it is accepted that the zero barrier height inhomogeneity is randomly distributed. The structure of the modeling device has columnar grains and gaps between the grains. Structure is divided microcells and every microcell is thought of as a single diode. Whole microcells are connected in parallel. The surface area of the microcells was assumed to be square and circle. In this study, the effect of zero barrier height inhomogeneity and the surface areas of the microcells on the current-voltage characteristics and interface state density are investigated.
\end{abstract}

Keywords: 2D device modeling, zero barrier height, inhomogeneity

\section{Au/n-GaN Schottky Aygıtının İki Boyutlu Modellenmesi}

ÖZET: Akım-voltaj karakteristikleri yanal homojensizliklerden güçlü bir şekilde etkilenir. Au/n-GaN Schottky aygıtı için iki boyutlu (2B) simülasyon modeli geliştirdik. Önceki çalışmalarda aygıtın sıfır voltluk gerilim altındaki engel yüksekliğindeki homojensizliğinin genellikle Gaussian dağılıma uyduğu varsayılmaktadır. Bu çalışmada, sıfır voltluk gerilim altındaki engel yüksekliğindeki homojensizliğin rastgele dağıldığı kabul edilmiştir. Modellenen aygıt yapısı sütunsu grainlere ve grainler arasında boşluklara sahiptir. Yapı mikro hücrelere ayrılmıştır ve her mikro hücre tek bir diyot olarak düşünülmüştür. Tüm mikro hücreler birbirlerine paralel bağlanmıştır. Mikro hücrelerin yüzey alanlarının kare ve daire olduğu varsayılmıştır. Bu çalışmada, mikro hücrelerin sıfır voltluk gerilim altındaki engel yüksekliğindeki homojensizliğinin ve yüzey alanlarının akım-voltaj karakteristikleri ve arayüzey durum yoğunluğuna etkileri incelenmiştir.

Anahtar Kelimeler: 2B aygıt modelleme, sıfır gerilimlendirme engel yüksekliği, homojensizlik

\footnotetext{
${ }^{1}$ Bengül METíN (Orcid ID: 0000-0002-8432-8569), Muğla Sitkı Koçman Üniversitesi, Muğla Meslek Yüksekokulu, Elektrik ve Enerji Bölümü, Muğla, Türkiye

${ }^{2}$ Neşe KAVASOĞLU (Orcid ID: 0000-0001-7249-2700), Abdulkadir Sertap KAVASOĞLU (Orcid ID: 0000-0001-67585574), Muğla Sitkı Koçman Üniversitesi, Fen Fakültesi, Fizik Bölümü, Muğla, Türkiye

*Sorumlu Yazar/Corresponding Author: Bengül METIN, e-mail: bzencir@mu.edu.tr

Bu çalışma Bengül METIN'in Doktora tezinden üretilmiştir.
}

Geliș tarihi / Received: 19-02-2020

Kabul tarihi / Accepted: 12-05-2020 


\section{INTRODUCTION}

Modeling and simulation is a method used to gain a broader perspective in multiple areas before any investment is made. So, expensive and inefficient processes are eliminated. Inputs and outputs that are difficult to reach by experimental methods can be easily obtained with the help of modeling and simulation.

Modeling and simulation provide a better understanding of the working principles of semiconductor devices and electronic circuits. Device simulation is the process of mathematical modelling, performed on a computer, which is designed to predict the behavior of the outcome of a realworld device performance. Since they allow to check the reliability of chosen mathematical models, computer simulations have become a useful tool for the mathematical modeling of many electronic components in device physics (computational physics). Across device manufacturing and electronic performance, simulation modeling provides valuable solutions by giving clear insights into real-world electronic performance. The power of computational device simulation is that it allows physicist to simulate variations more efficiently by computer, saving time, money, and materials. Virtual experiments with simulation models are less expensive and take less time than experiments with real assets. Electronic device performance can be tested without unnecessarily spending money and time. Because of the computational cost of simulation, computer experiments are used to perform inference such as uncertainty quantification. There are lots of published articles on modeling and simulation in the literature (Bai et al., 2018; Yu et al., 2019; Sowmya et al., 2019; Garcia et al., 2019; Boudaoud et al., 2020; Huang et al., 2020; Ferhati et al.,2020).

In this simulation study, we focused on $\mathrm{Au} / \mathrm{n}-\mathrm{GaN}$ Schottky device. $\mathrm{GaN}$ has a band gap of $3.4 \mathrm{eV}$ and a highly preferred material for photovoltaic energy conversation, detectors, production of LED's, lasers, fiber optic communication, atmosphere monitoring aplications, high frequency transistors- power - temperature, solar cells for space applications (Peartona et al., 2000; Dobos et al., 2006; Mou et al., 2017). Au, Ni, Pt and Pd are used for production of GaN Schottky solar cells. In this study, it is chosen $\mathrm{Au}$, because of it is prominent features such as light transmission, photoresponse and thermal stability limits (Karrer et al., 1999; Touzi et al., 2002; Kadaoui et al., 2015).

One-dimensional (1D) simulation softwares are used to investigate solar cell behavior in the literature. Fabricated devices has inhomogeneous structure due to the growth conditions. 1D simulation programs are unsatisfactory to study these inhomogeneous structures like separate shunts, poor diode areas, contact geometries and grain borders (Miettunen et al., 2011). For this reason, two-dimensional (2D) simulation programs are used for inhomogeneous structures (Malm and Edoff, 2009).

In this study, 2D simulation program were developed for Au/n-GaN Schottky device. Currentvoltage data were obtained from the simulation program. The influence of non-uniform zero barrier height on I- V graphs was investigated. 2D interface state density was also examined. The effect of surface area of the microcells on electrical properties was examined for two cases. The surface area of the microcells was assumed to be square and circle.

\section{MATERIALS AND METHODS}

The energy band diagram of $\mathrm{Au} / \mathrm{n}-\mathrm{GaN}$ Schottky device under zero bias condition is illustrated in Figure 1. The illuminated and dark current-voltage data are obtained for $6400 \times 4600 \mu \mathrm{m}^{2}$ of Au/n-GaN Schottky device by our modeling program at room temperature. Electronic equivalent circuit of the device is given at Figure 2. Inhomogeneous structures host different grain orientations, irregular grain borders and in joint fluxations. The structural dislocations produce unusual electronic device parameters. Modeled inhomogeneous device is divided microcells owing to these grains. Every microcell is 
considered as a single diode. There are a total of 2944 units diode in the device. All microcells are connected in parallel.

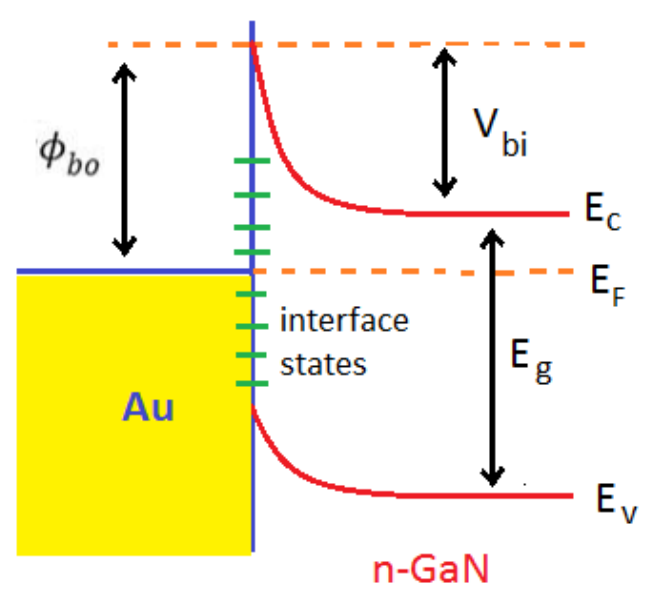

Figure 1. Energy band diagram of $\mathrm{Au} / \mathrm{n}-\mathrm{GaN}$ Schottky device

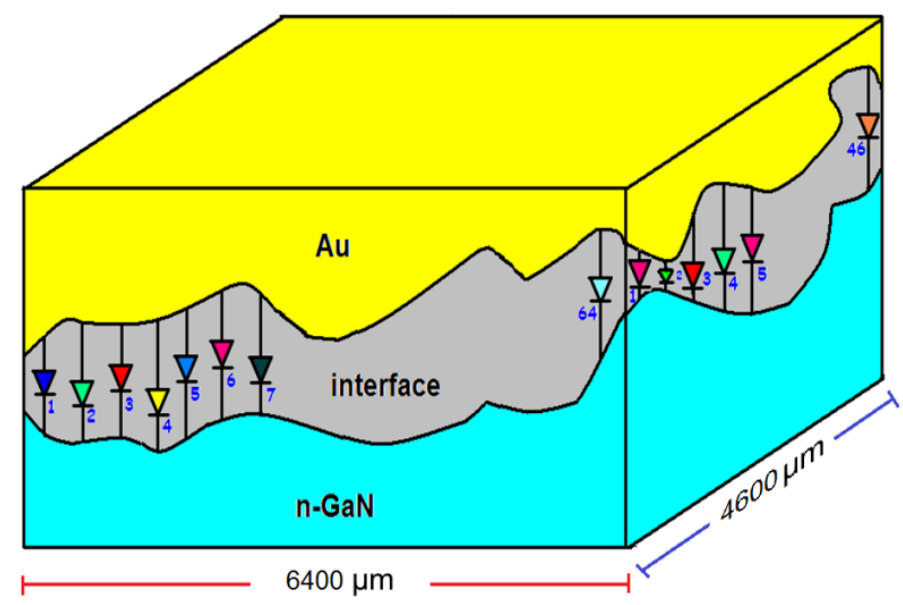

Figure 2. Designed electronic equivalent circuit for developed 2D device modeling program

In this study, developed 2D modeling software is used for obtaining current voltage characteristics of the $\mathrm{Au} / \mathrm{n}-\mathrm{GaN}$ Schottky device. Inhomogeneity in device parameters is often thought to be in well agreement with Gaussian distribution is consistent with this reported in previous works (Zhu et al., 2000; Tataroğlu and Altındal, 2009; Badalia et al., 2018). Also, surface area of the microcells is taken into account as equivalent squares in the previous study (Koishiyev and Sites, 2009). In this study, inhomogeneity in device parameters has been adopted to obey random distribution and surface area of the microcells examined for two cases. The surface area of the microcells was assumed to be equivalent squares and circles as seen in Figure 3.

Random fluctuations in the zero barrier height are shown in Figure 4. These random fluctuations were achieved with Random number generator (RND) of the computer's (Formula 1). In our developed model, random fluctuations due to inhomogeneity is represented by gamma $(\Gamma)$. Calculations were made for all values of gamma $(0,0.05,0.1,0.15,0.2)$ of zero barrier height. For example, when the gamma is 0.2 , fluctuations in the zero barrier height are given in Figure 4. Offset value of zero barrier height was determined with the help of the early experimentel study (Das and Pal, 2007). Zero barrier height variation for the each microcell in the device has been considered for inhomogeneous $\mathrm{Au} / \mathrm{n}-\mathrm{GaN}$ 
Schottky device. Flow chart of 2D device modeling program is given in the study of Kavasoğlu et al. (2016).

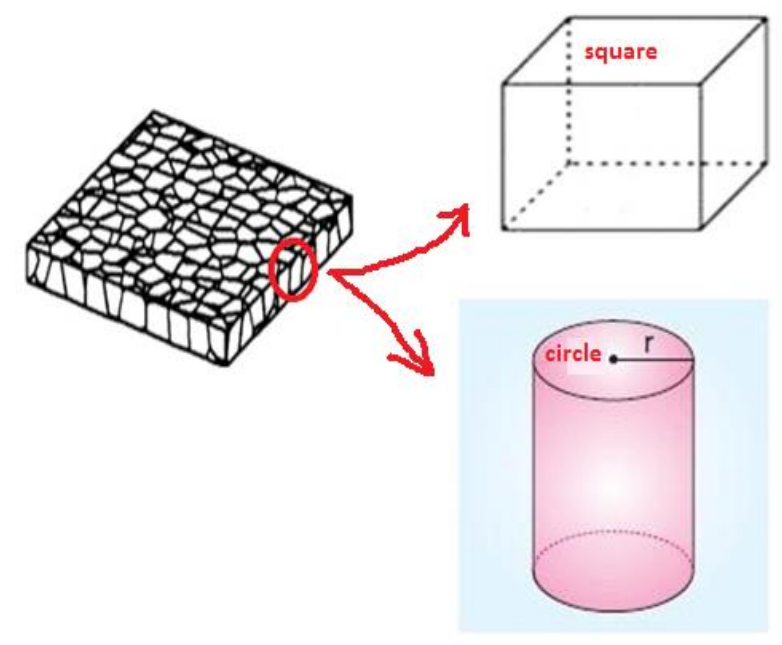

Figure 3. Two different surface areas for the microcells



Figure 4. Example of the fluctuations in the zero barrier height (for $\Gamma$ is $\% 20=0.2$ )

In this work, its proposed that there are 2944 parallel microcells with different zero barrier height and the total current is formed by individual contribution of microcells. The modeled device has a parasitic resistance for all microcells and each microcells have individual shunt resistances. We have operated 2D simulation program to survey dependence of $\mathrm{I}-\mathrm{V}$ characteristics on zero barrier height fluctuations in the device with square surface and circle surface of the grains. In this work, simulation data presented, deals with at room temperature and AM0 solar spectrum.

\section{RESULTS AND DISCUSSION}

Spatially inhomogeneus structre has randomly distributed dopant atoms, lattice defects in interface, different orientation and grain boundaries of metal atoms and semiconductor, interface roughness. The structural anomalies cause non-ideal device parameters. Non-uniform metalsemiconductor interfaces are mimic parallel contacts between metal and semiconductor. For simulation purposes, device is divided microcells and every microcell is considered as a single diode and whole the microcells are connected in parallel. 
It is considered that the zero barrier heights in the non-uniform $\mathrm{Au} / \mathrm{n}-\mathrm{GaN}$ Schottky device fluctuate randomly. Surface area of the microcells evaluated for two cases. In the first case, the surface area of each microcell was considered as square. The edge length of the microcell surface is $100 \mu \mathrm{m}$. These diodes are placed (64) horizontal axes and (46) vertical axes as seen Figure 2. Illuminated current voltage characteristics were carried out by using a simulation program developed for $\mathrm{Au} / \mathrm{n}-\mathrm{GaN}$ Schottky device.

The effect of square surface area of the microcell and different inhomogeneity levels of the zero barrier height on the illuminated I-V graphs is seen in Figure 5. Minimum and maximum values of zero barrier heights are decided using fluctuation factor value. In this study, zero barrier heights of diodes differ from each other according with the following formula;

$$
\phi_{b o j}=\phi_{b o}(0)+\left(\Gamma \phi_{b o}(0)\right)(2 R N D-1)
$$

In this equation, $\mathrm{j}$ is the cell number, $\Gamma$ is fluctuation factor (measure of inhomogeneity), RND is a randomly generated number ranging from 0 to $1, \phi_{b o}(0)$ is offset value of zero bias barrier height. Figure 4 gives an example of random fluctuations of the zero barrier height in the device.

As shown in Figure 5, while inhomogeneity of the zero barrier height increases, $V_{\text {oc }}$ values are decreased for square surface area of the microcells. Good agreement was obtained between the simulation results and results reported by Grabitz et al and Abass et al (Grabitz et al., 2005; Abass et al., 2013).

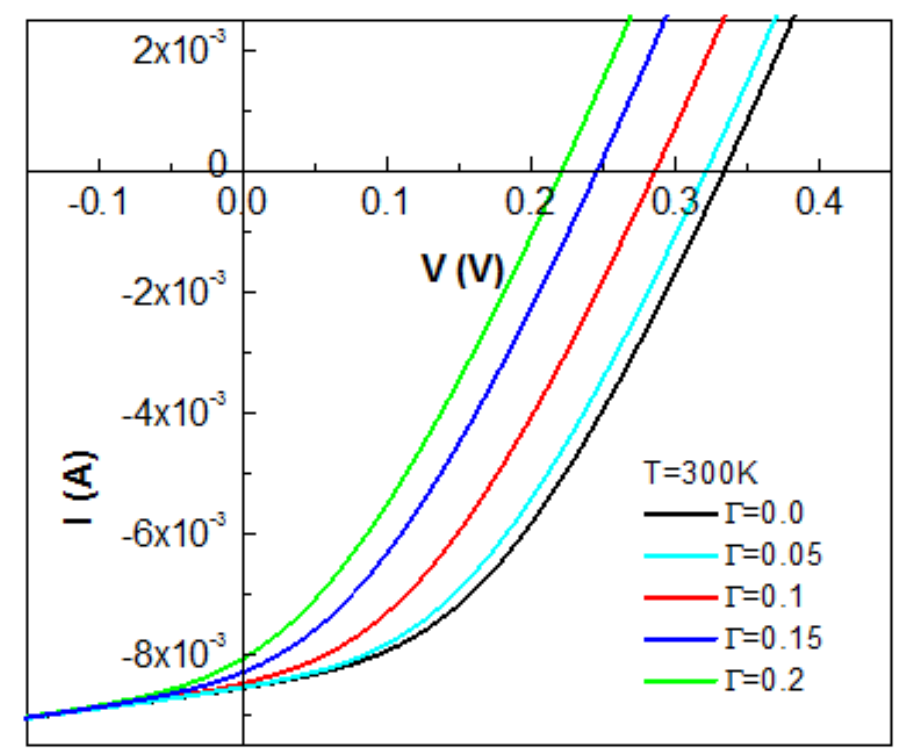

Figure 5. Illuminated current of square-shaped diode in the function of voltage for several values of random fluctuation factors $(\Gamma)$

In the second case, the surface area of the microcells was assumed to be circles, exhibiting a random distribution of radius within $40-50 \mu \mathrm{m}$ range. The total number of diodes is 2944 . Figure 6 represents the illuminated current voltage characteristics for circle surface area and different zero barrier height inhomogeneity of the microcells of the Au/n-GaN Schottky device for room temperature. 


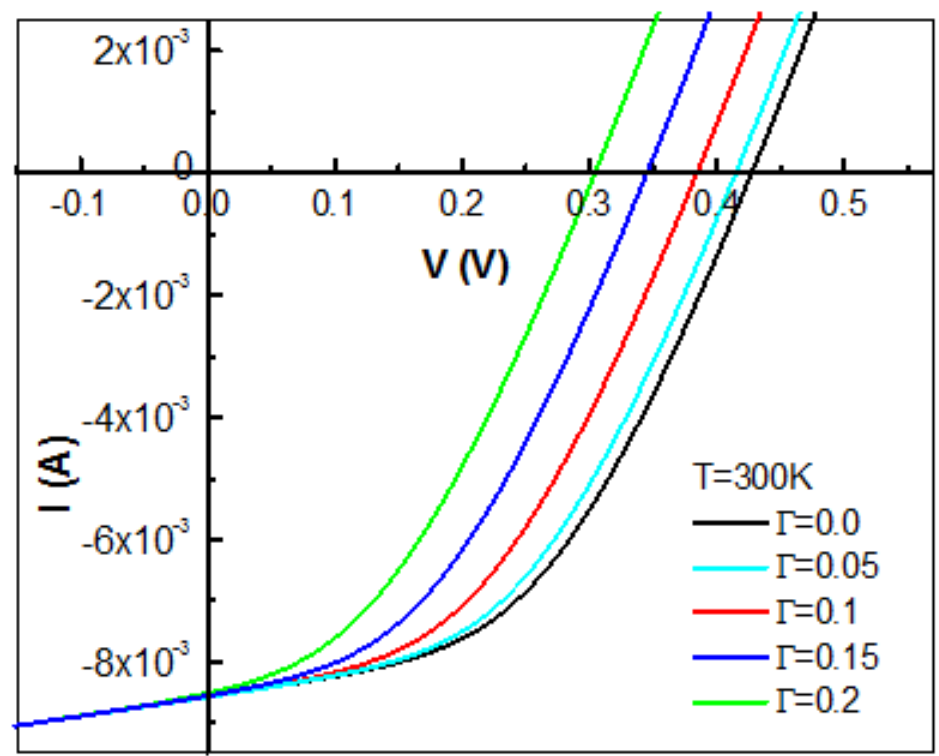

Figure 6. Illuminated current of circle-shaped diode in the function of voltage for several values of random fluctuation factors $(\Gamma)$

Figure 6 shows the variation of illuminated current voltage characteristics with zero barrier height fluctuating factor. While the inhomogeneity of the zero barrier height increases, $V_{\text {oc }}$ values are decreased. Also, when suppose that shape of a surface is the circle, $\mathrm{V}_{\text {oc }}$ values are increased with respect to previous microcell surface shape.

Zero barrier height fluctuating factor and different kinds of surfaces dependent fill factor and efficiency are demonstrated in Figure 7 . While zero barrier height fluctuation factor increases, $V_{\text {oc }}$, efficiency and fill factor decreases as seen in Figure 5-6-7. It is seen that, efficiency and fill factor values have higher values for circle-shaped microcell surface than square-shaped microcell surface.

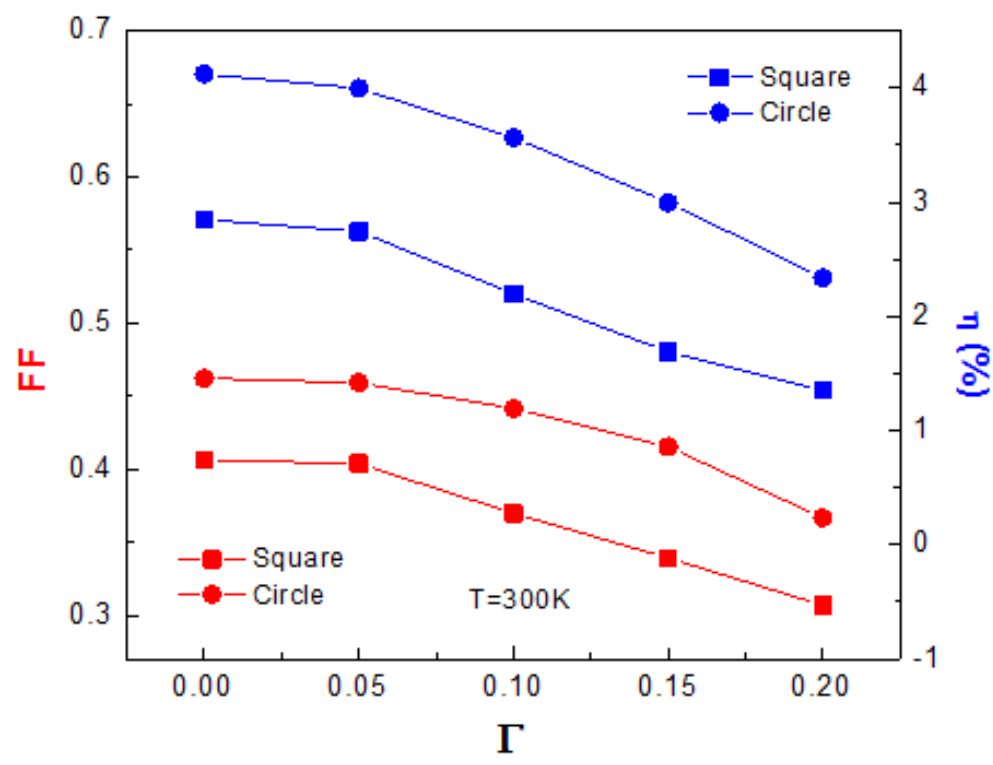

Figure 7. The variation of the FF and the $\eta$ with random fluctuation factors $(\Gamma)$ for different types of surface shapes

To investigate, how the interface state density affects the current conduction mechanism of the diodes, Card and Rhoderick's relations have been used (Card and Rhoderick, 1971). n(V) (diode factor) can be define as; 


$$
n(V)=\frac{q\left(V-I R_{S}\right)}{k_{B} T \ln \left(\frac{I}{I_{O}}\right)}
$$

Interface state density is given with following equation (Cowley and Sze, 1965; Özdemir and Altındal, 1994);

$$
N_{s S}(V)=\frac{1}{q}\left[\frac{\varepsilon_{i}}{\delta}(n(V)-1)-\frac{\varepsilon_{S}}{W_{d}}\right]
$$



(a)

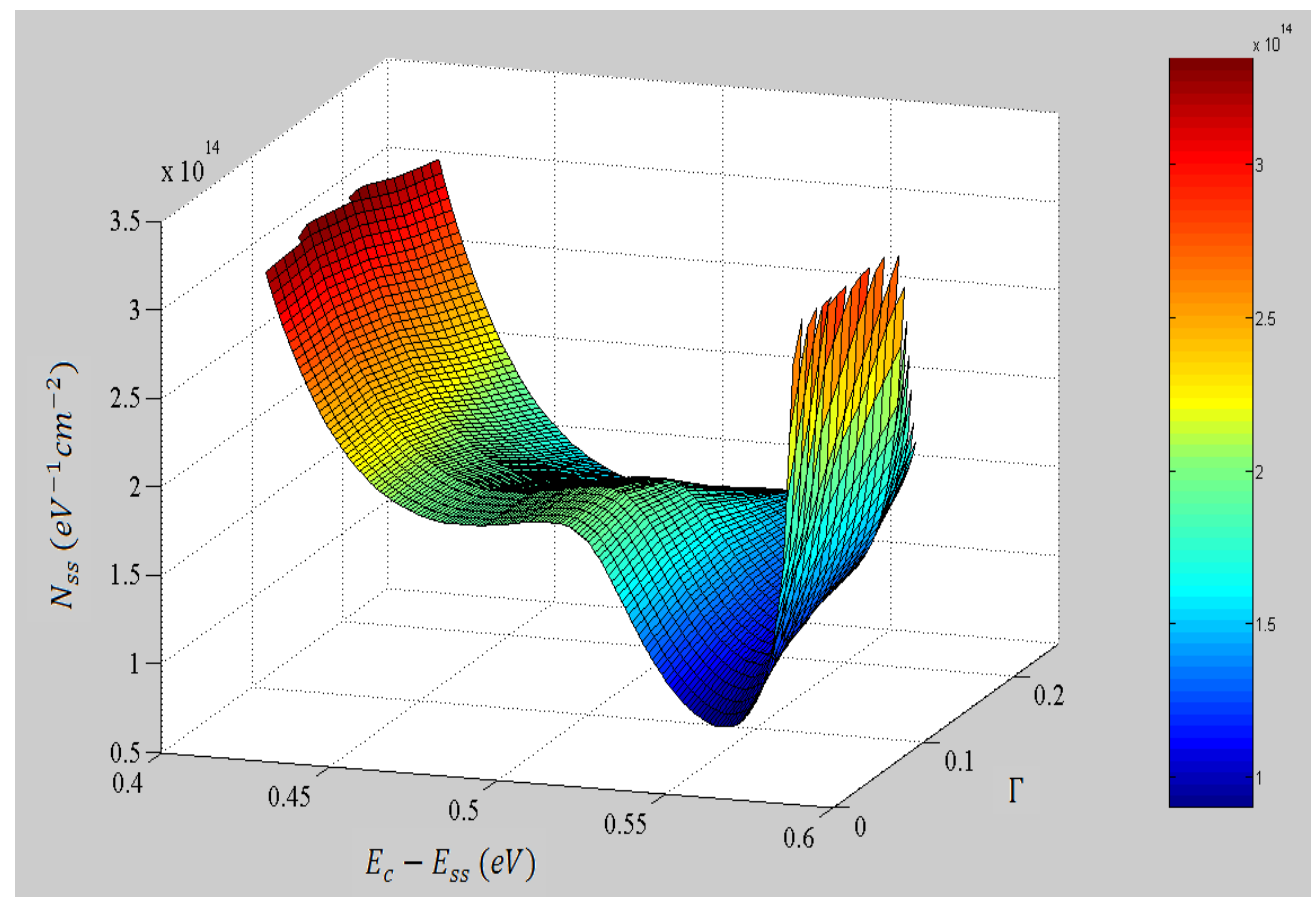

(b)

Figure 8. $\mathrm{N}_{\mathrm{ss}}-\left(\mathrm{E}_{\mathrm{c}}-\mathrm{E}_{\mathrm{ss}}\right)-\Gamma$ variation (a) Square, (b) Circle 
Where $W_{d}$ is the space charge region width, $\delta$ is the interfacial insulator layer thickness, $\varepsilon_{s}$ and $\varepsilon_{i}$ permittivity of the semiconductor and interfacial insulator layer, respectively.

Effective barrier height is identified with following equation $\left(\phi_{e}\right)$ (Cova and Singh, 1990; Altındal et al., 2003; Afandiyeva et al., 2008);

$$
\phi_{e}=\phi_{b o}+\left(1-\frac{1}{n(V)}\right)\left(V-I R_{S}\right)
$$

$E_{S S}$ is the energy of the interface states at the Schottky joint interface. $E_{S S}$ with respect to the bottom of the conduction band at the surface of the n-type semiconductor is given by (Cova and Singh, 1990)

$$
E_{c}-E_{s S}=q\left[\phi_{e}-\left(V-I R_{S}\right)\right]
$$

Figure 8 (a),(b) shows the $N_{S S}$ curves. $N_{S S}-\left(E_{c}-E_{S S}\right)$ curves are susceptible to shape of a surface and fluctuation factor of zero barrier height of the microcells.

\section{CONCLUSION}

In this study, developed 2D modeling software is used for obtaining current voltage characteristics of $\mathrm{Au} / \mathrm{n}-\mathrm{GaN}$ Schottky device. Au/n-GaN Schottky device has been investigated with taking zero barrier height fluctuating into account by simulation. $\mathrm{V}_{\mathrm{oc}}$, interface state density, efficiency and fill factor greatly depend on random fluctuating factor of zero barrier height. Also, surface shape of the microcells in the simulated device has been examined for two cases (square and circle). $\mathrm{V}_{\text {oc }}$, efficiency and fill factor have higher values for the circle-shaped microcell compared to the square-shaped microcell. Interface state density is also responsive to shape of surface and fluctuation factor of zero barrier height of the microcells.

\section{REFERENCES}

Abass A, Van Gestel D, Van Wichelen K, Maes B, Burgelman M, 2013. On the diffusion lenght and grain size homogeneity requirements for efficient thin-film polycrystalline silicon solar cells. Journal of Physics D: Applied Physics, 46: 045105-045115.

Afandiyeva IM, Dökme I, Altındal Ş, Abdullayeva LK, Askerov SG, 2008. The frequency and voltage dependent electrical characteristics of $\mathrm{Al}-\mathrm{TiW}-\mathrm{Pd} \mathrm{d}_{2} \mathrm{Si} / \mathrm{n}-\mathrm{Si}$ structure using $\mathrm{I}-\mathrm{V}, \mathrm{C}-\mathrm{V}$ and $\mathrm{G} / \mathrm{w}-\mathrm{V}$ measurements. Microelectron Eng., 85: 365-370.

Altındal Ş, Karadeniz S, Tuğluoğlu N, Tataroğlu A, 2003. The role of interface states and series resistance on the $\mathrm{I}-\mathrm{V}$ and $\mathrm{C}-\mathrm{V}$ characteristics in $\mathrm{Al} / \mathrm{SnO}_{2} / \mathrm{p}-\mathrm{Si}$ Schottky diodes. Solid-State Electronics, 47: 1847-1854.

Badalia Y, Altındal Ş, Uslu İ, 2018. Dielectric properties, electrical modulus and current transport mechanisms of $\mathrm{Au} / \mathrm{ZnO} / \mathrm{n}-\mathrm{Si}$ structures. Progress in Natural Science: Materials International, 28: 325-331.

Bai Z, Du J, Xin Q, Li R, Yu Q, 2018. Numerical analysis of the reverse blocking enhancement in High-K passivation AlGaN/GaN Schottky barrier diodes with gated edge termination. Superlattices and Microstructures, 114: 143-153.

Boudaoud C, Hamdoune A, Allam Z, 2020. Simulation and optimization of a tandem solar cell based on InGaN. Mathematics and Computers in Simulation, 167: 194-201.

Card HC, Rhoderick EH, 1971. Studies of tunnel MOS diodes I. Interface effects in silicon Schottky diodes. J. Appl. Phys., 4: 1589-1601.

Cova P, Singh A, 1990. Temperature dependence of $I-V$ and $C-V$ characteristics of $\mathrm{Ni} / n-\mathrm{CdF}_{2}$ Schottky barrier type diodes. Solid-State Electron, 33: 11-19.

Cowley AM, Sze SM, 1965. Surface States and Barrier Height of Metal-Semiconductor Systems. Journal of Applied Physics, 36: 3212-3220. 
Das SN, Pal AK, 2007. Schottky diodes based on nanocrystalline $\mathrm{p}-\mathrm{GaN}$ and $\mathrm{n}-\mathrm{GaN}$ in thin film form. Vacuum, 81: 843-850.

Dobos L, Pecz B, Toth L, Horvath Zs J, Horvath ZE, Toth A, Horvath E, Beaumont B, Bougrioua Z, 2006. Metal contacts to n-GaN. Applied Surface Science, 253: 655-661.

Ferhati H, Djeffal F, Drissi LB, 2020. A new approach to the modeling and simulation of multi-junction solar cells. Optik, 200: 163452.

Garcia F, Shamsir S, Islam SK, 2019. A compact model and TCAD simulation for GaN-gate injection transistor (GIT). Solid-State Electronics, 151: 52-59.

Grabitz PO, Rau U, Werner JH, 2005. Modeling of spatially inhomogeneous solar cells by a multi-diode approach. Phys. Stat. Sol. (a), 202: 2920-2927.

Huang R, Yu M, Yang Q, Zhang L, Wu Y, Cheng Q, 2020. Numerical simulation for optimization of an ultrathin n-type $\mathrm{WS}_{2} / \mathrm{p}$-type c-Si heterojunction solar cells. Computational Materials Science, 178: 109600.

Kadaoui MA, Bouiadjra WB, Saidane A, Belahsene S, Ramdane A, 2015. Electrical parameters of Au/n-GaN and $\mathrm{Pt} / \mathrm{n}-\mathrm{GaN}$ Schottky diodes. Superlattices and Microstructures, 82: 269-286.

Karrer U, Dobner A, Ambacher O, Stutzmann M, 1999. Characterization of AlGaN-Schottky Diodes Grown by Plasma Induced Molecular Beam Epitaxy. Phys. Stat. Sol. (a), 176: 163-167.

Kavasoğlu N, Kavasoğlu AS, Metin B, 2016. A New Simulation Model for Inhomogeneous Au/n-GaN Structure. Semiconductors, 50(5): 616-620.

Koishiyev GT, Sites JR, 2009. Effect of Shunts on Thin-Film CdTe Module Performance. Mater. Res. Soc. Symp. Proc., 1165.

Malm U, Edoff M, 2009. 2D device modelling and finite element simulations for thin-film solar cells. Solar Energy Materials \& Solar Cells, 93: 1066-1069.

Miettunen K, Halme J, Visuri AM, Lund P, 2011. Two- Dimensional Time-Dependent Numerical Modeling of Edge Effects in Dye Solar Cells. The Journal of Physical Chemistry C, 115: 7019-7031.

Mou W, Zhao L, Chen L, Yan D, Ma H, Yang G, Gu X, 2017. GaN-based Schottky barrier ultraviolet photodedectors with graded doping on patterned sapphire substrates. Solid-State Electronics, 133: 78-82.

Özdemir S, Altındal Ş, 1994. Temperature Dependent Electrical Characteristics of Al-SiOx-pSi Solar Cells. Sol. Energ. Mat. Sol. C, 32: 115-127.

Peartona SJ, Ren F, Zhang AP, Lee KP, 2000. Fabrication and performance of GaN electronic devices. Materials Science and Engineering, R30: 55-212.

Sowmya K , Balamurugan NB, Parvathy V, 2019. A 2-D Modeling of Fe doped Dual Material Gate AlGaN/AlN/GaN High Electron Mobility Transistors for High Frequency Applications. AEU International Journal of Electronics and Communications, 103: 46-56.

Tataroğlu A, Altındal Ş, 2009. The distribution of barrier heights in MIS type Schottky diodes from currentvoltage-temperature ( $I-V-T)$ measurements. Journal of Alloys and Compounds, 479 (1-2): 893-897.

Touzi C, Rebey A, Eljani B, 2002. Influence of metal properties and photodiode parameters on the spectral response of n-GaN Schottky photodiode. Microelectronics Journal, 33: 961-965.

Yu M, Li Y, Cheng Q, Li S, 2019. Numerical simulation of graphene/GaAs heterojunction solar cells. Solar Energy, 182: 453-461.

Zhu S, Detavernier C, Van Meirhaeghe RL, Cardon F, Ru G, Qu X, Li B, 2000. Electrical characteristics of CoSi 2 /n-Si (100) Schottky barrier contacts formed by solid state reaction. Solid-State Electronics, 44: 1807-1818. 